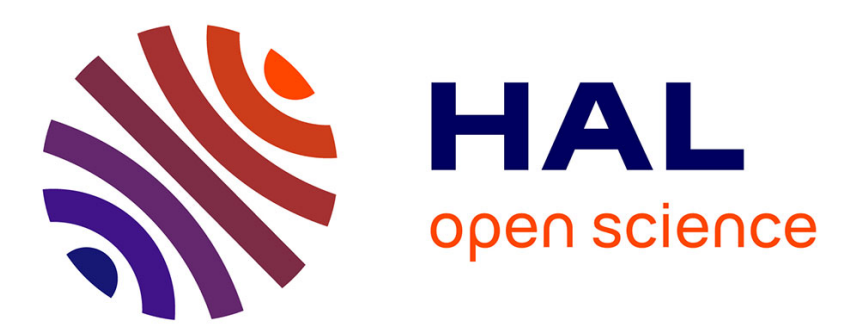

\title{
A New Generation of Sterile and Radiopaque Impression Materials-an Cytotoxicity Study
}

Chiara Coppi, Chiara Paolinelli Devincenzi, Sergio Bortolini, Ugo Consolo, Roberta Tiozzo

\section{- To cite this version:}

Chiara Coppi, Chiara Paolinelli Devincenzi, Sergio Bortolini, Ugo Consolo, Roberta Tiozzo. A New Generation of Sterile and Radiopaque Impression Materials-an Cytotoxicity Study. Journal of Biomaterials Applications, 2007, 22 (1), pp.83-95. 10.1177/0885328206071928 . hal-00570775

\section{HAL Id: hal-00570775 \\ https://hal.science/hal-00570775}

Submitted on 1 Mar 2011

HAL is a multi-disciplinary open access archive for the deposit and dissemination of scientific research documents, whether they are published or not. The documents may come from teaching and research institutions in France or abroad, or from public or private research centers.
L'archive ouverte pluridisciplinaire HAL, est destinée au dépôt et à la diffusion de documents scientifiques de niveau recherche, publiés ou non, émanant des établissements d'enseignement et de recherche français ou étrangers, des laboratoires publics ou privés. 


\title{
A New Generation of Sterile and Radiopaque Impression Materials-an in vitro Cytotoxicity Study
}

\author{
Chiara Coppi, ${ }^{1}$ Chiara PaOlinelli Devincenzi, ${ }^{2}$ Sergio Bortolini, ${ }^{1}$ \\ Ugo CONSOLO ${ }^{1}$ AND RoBerta TIOZZO ${ }^{2, *}$ \\ ${ }^{1}$ Department of Neurosciences, Section of Dentistry, University of Modena and \\ Reggio Emilia, Policlinico, Largo del Pozzo 71, 41100 Modena, Italy \\ ${ }^{2}$ Department of Biomedical Sciences, Section of General Pathology, University of \\ Modena and Reggio Emilia, Via G. Campi 287, 41100 Modena, Italy
}

\begin{abstract}
Impression materials are largely used to record the geometry of dental tissue. Hence, the assessment of their possible cytotoxicity is a necessary step in the evaluation of their biocompatibility. The present study is carried out to evaluate the cytotoxicity of a new elastomeric sterile and radiopaque impression material. Human gingival fibroblasts, cultured in vitro are exposed directly to Elite Implant in three different viscosities, heavy, medium, and light. At $3,9,24,48$, and $72 \mathrm{~h}$, the cellular proliferation is evaluated. In parallel, human gingival fibroblasts are exposed indirectly by means of fluid extracts of Elite Implant. The cellular viability is evaluated by 3-[4,5-dimethylthiazol-2-yl]2,5-diphenyltetrazolium bromide, (MTT) assay (Sigma, St Louis, Mo). The gingival fibroblasts proliferation and viability are unaffected by the presence of Elite Implant. This new impression material may represent a safe medical device for clinical and surgical applications. In addition, this material is radiopaque and, thus, can be identified radiographically.
\end{abstract}

KEY WORDS: dental impression material, human gingival fibroblast, in vitro cytotoxicity tests, proliferation, viability.

\footnotetext{
*Author to whom correspondence should be addressed.

E-mail: tiozzo.roberta@unimore.it
} 


\section{INTRODUCTION}

A 11 dental impression materials should accurately replicate $A$ intraoral and extraoral tissues in terms of accuracy, dimensional stability, elasticity, tear strength, rigidity, reproduction of detail, and biocompatibility [1]. ISO 10993 is used to determine the safety of medical devices by defining various types of biocompatibility tests. Cellular toxicity testing, which is required for all types of medical devices, is covered in ISO 10993-5 [2].

Four types of elastomers are extensively used: polysulfides, condensation silicones, polyethers, and vinyl polysiloxanes [3]. They are generally supplied in two paste forms, base and catalyst, and may be dispensed through an auto-mixing cartridge. Although polyethers present many advantages for clinical use, several disadvantages have been reported including allergic and toxic reactions, contact dermatitis, and gingivitis [4-11]. Vinyl polysiloxanes are more commonly used [3]. Various studies have reported contradictory levels of toxicity of vinyl polysiloxanes, classified as toxic [7-10], less toxic [8], or non-toxic [9-11]. The different grades of toxicity, evaluated in vitro, depend on the type of culture (primary cell or permanent cell lines), on the type of in vitro test (direct or indirect), and on the manufacturing processes of the materials.

The toxicity of dental impression materials is especially important when, during an intervention, a fragment becomes entrapped and remains within the gingival sulcus $[12,13]$ under the suture, during impression making for implants or a surgical prosthesis. Fragments of impression materials have been found in soft tissues [14-20], under the periosteum [15,21-23], in the spongy bone [24-26], and in the maxillary sinus [27-30]. This can also occur in implant dentistry, particularly during second stage implant surgery or during single stage surgery. The retention of these fragments can induce a severe inflammatory reaction [15-17,20,22,26], which can result in implant failure.

An in vivo study recently reported postoperative problems following root canal treatment [20]. One week after filling, the patient presented with a painful swelling associated with the treated tooth. Following clinical examination, a thin piece of residual polyether impression material left in the tissues was identified as the possible cause of the swelling. This material was transparent, and not detected by radiographic examination. A clinical report highlights the importance of the radiopacity of any impression material for assisting in location and retrieval of accidentally embedded materials [23].

The purpose of this study was to investigate the cytotoxicity of a new vinyl polysiloxane, which is both sterile and radiopaque. 


\section{MATERIALS AND METHODS}

\section{Impression Materials}

The heavy, medium, and light forms of Elite Implant (Zhermack, Badia Polesine, Rovigo, Italy), which are both sterile and radiopaque, were studied.

\section{Cell Culture}

Human gingival fibroblasts were chosen because they represent a good simulation of the in vivo condition particularly in cases of impression material retention [31] in the gum.

Human gingival fibroblasts were isolated from biopsies of a healthy subject, after providing informed consent, who was undergoing gingivectomy of the molar region. Immediately after removal, the biopsies were placed in collection medium consisting of Hank's balanced salt solution (HBSS) (Gibco, Grand Island, New York), containing $250 \mathrm{UI} / \mathrm{mL}$ penicillin and $0.25 \mathrm{mg} / \mathrm{mL}$ streptomycin, $0.05 \mathrm{mg} / \mathrm{mL}$ gentamycin, and $0.0025 \mathrm{mg} / \mathrm{mL}$ amphotheracin B (all from Gibco). The fibroblasts were grown as previously described [9,31-33]. The cells were cultured in Dulbecco's modification of Eagle's medium (DMEM) (Gibco), supplemented with $10 \%$ fetal bovine serum (FCS) (Gibco), $50 \mathrm{UI} / \mathrm{mL}$ penicillin, $50 \mu \mathrm{g} / \mathrm{mL}$ streptomycin, $2 \mathrm{mM}$ L-glutamine (Gibco), and $1 \mathrm{mM} \mathrm{Na}$ piruvate (Sigma, St Louis, Mo) at $37^{\circ} \mathrm{C}$ in humidified atmosphere, $95 \%$ air, and $5 \% \mathrm{CO}_{2}$. The culture reached confluence in $7 \mathrm{~d}$ and was then subcultured until the experiments were initiated. In the study, the cultures were used to the sixth passage.

\section{Measurements of Cytotoxicity}

The direct and indirect tests of cytotoxicity were carried out following pre-defined methodology [8,33,34] with some modifications [9].

\section{Direct Cytotoxicity Test}

Human gingival fibroblasts, $20 \times 10^{4}$, were plated, in duplicate, in $60 \mathrm{~mm}$ petri dishes (Falcon, BD Bioscience, Milano, Italy) in a total volume of $5 \mathrm{~mL}$ of culture medium with $10 \%$ FCS and antibiotics, both in the presence and the absence of impression materials and their components. The polymerized impression materials $\left(1 \mathrm{~cm}^{2}\right)$ were 
placed in the center of the petri dishes under sterile conditions. The dishes were incubated at $37^{\circ} \mathrm{C}$ under a humidified atmosphere of $95 \%$ air and $5 \% \mathrm{CO}_{2}$. Cell proliferation was evaluated after 3, 9, 24, 48, and $72 \mathrm{~h}$. At each time period the medium was removed, cells in monolayer were trypsinized (Na-EDTA trypsin) (Gibco) for 7-10 min, and counted in a hemocytometer (Neubauer). Data were analyzed statistically using Student's test and statistical significance was set up, $p<0.05$. Reported values are the mean of four replicates \pm standard deviation.

\section{Indirect Cytotoxicity Test}

The indirect test was performed by incubating impression materials $\left(1 \mathrm{~cm}^{2}\right)$ in petri dishes, in $5 \mathrm{~mL}$ of culture medium without FCS for $24 \mathrm{~h}$ at $37^{\circ} \mathrm{C}$ under sterile conditions. At the end of the incubation period, the soluble extracts of these impression materials were collected in tubes and enriched with 10\% FCS (Gibco). Human gingival fibroblasts were plated at $20 \times 10^{3}$ per well in 24 -well plates (Falcon; BD Bioscience) in $2 \mathrm{~mL}$ of culture medium. When the cell cultures were sub-confluent, the medium was removed; the cell monolayer was washed with PBS and exposed to diluted (50\%) or undiluted (100\%) soluble extracts at 12 and $24 \mathrm{~h}$. Each concentration was tested in quadruplicate wells together with appropriate controls. At the end of the treatment, cell viability was estimated by 3-[4,5-dimethylthiazol-2-yl]-2,5-diphenyltetrazolium bromide (MTT) assay (Sigma, St Louis, Mo) [9,34]. The MTT assay is an indirect marker for cytotoxicity. It is based on the ability of cells to reduce the slightly yellow soluble MTT to a deep purple formazan product, insoluble in aqueous solution. The reaction is catalyzed by mitochondrial succynil dehydrogenase.

After $24 \mathrm{~h}$ of cell culture in the presence of undiluted or diluted extracts of impression materials, the medium was removed and $2 \mathrm{~mL}$ of growth medium with $200 \mu \mathrm{L}$ of MTT $(5 \mathrm{mg} / \mathrm{mL}$ in PBS) were added to the cultures. Cells were incubated, in the dark, at $37^{\circ} \mathrm{C}$ in a humidified atmosphere $\left(95 \%\right.$ air and $5 \% \mathrm{CO}_{2}$ ) for $3 \mathrm{~h}$. The growth medium was removed, $2 \mathrm{~mL}$ of dimethyl sulfoxide (DMSO; Sigma) were added to each well to dissolve the purple formazan. The absorbance was measured in a spectrophotometer at a wavelength of $540 \mathrm{~nm}$. This parameter is an indicator of the functional integrity of the mitochondria, and hence of cellular viability. Reported values are the mean of four replicates \pm standard deviation and are expressed as percentages of the control values. 

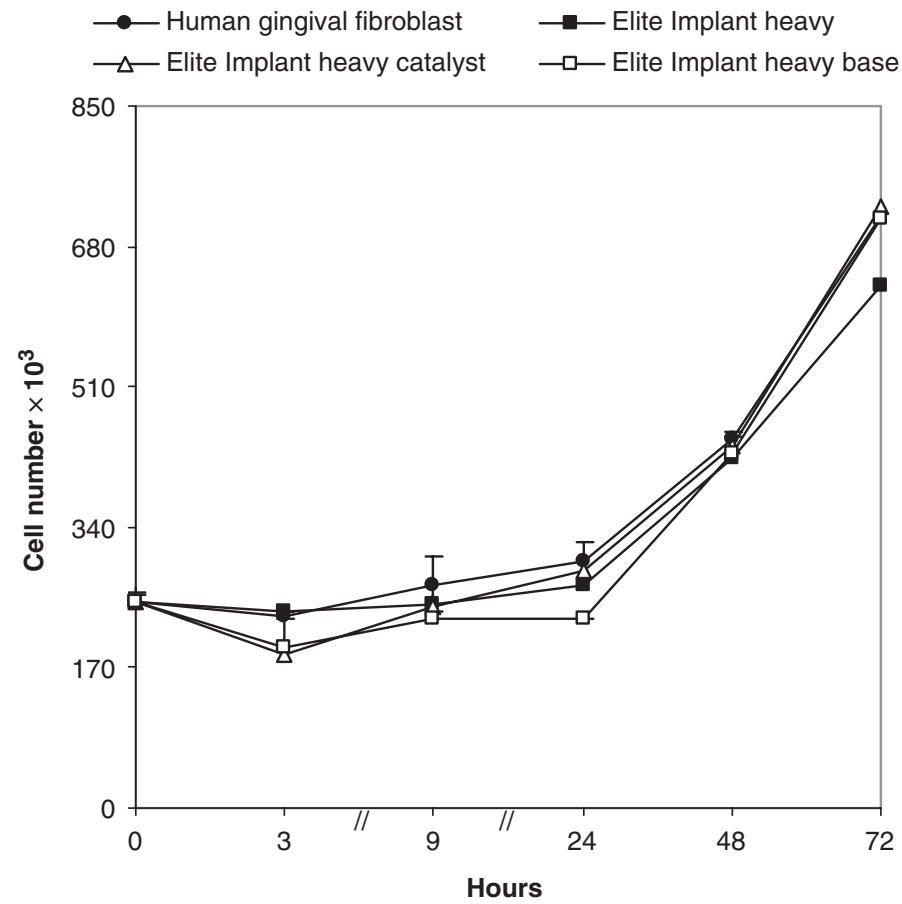

Figure 1. Direct effect of Elite Implant heavy viscosity polymerized and its components, base and catalyst pastes, on in vitro proliferation of human gingival fibroblasts. Each point represents the mean of four measurements \pm SD.

\section{Morphological Analysis}

Human gingival fibroblasts were observed through an inverted microscope in phase contrast mode at $\times 50$ magnification (Nikon Diaphot-TMD) and photographed after 3, 9, 24, 48, and $72 \mathrm{~h}$ of culture both in the presence and the absence of impression materials and their components.

\section{RESULTS}

\section{Direct Effect of Elite Implant Polymerized and its Components - Base and Catalyst Pastes - On the Proliferation of Human Gingival Fibroblasts}

The direct effect of polymerized Elite Implant heavy viscosity was evaluated at $3,9,24,48$, and $72 \mathrm{~h}$ in culture. The impression materials 


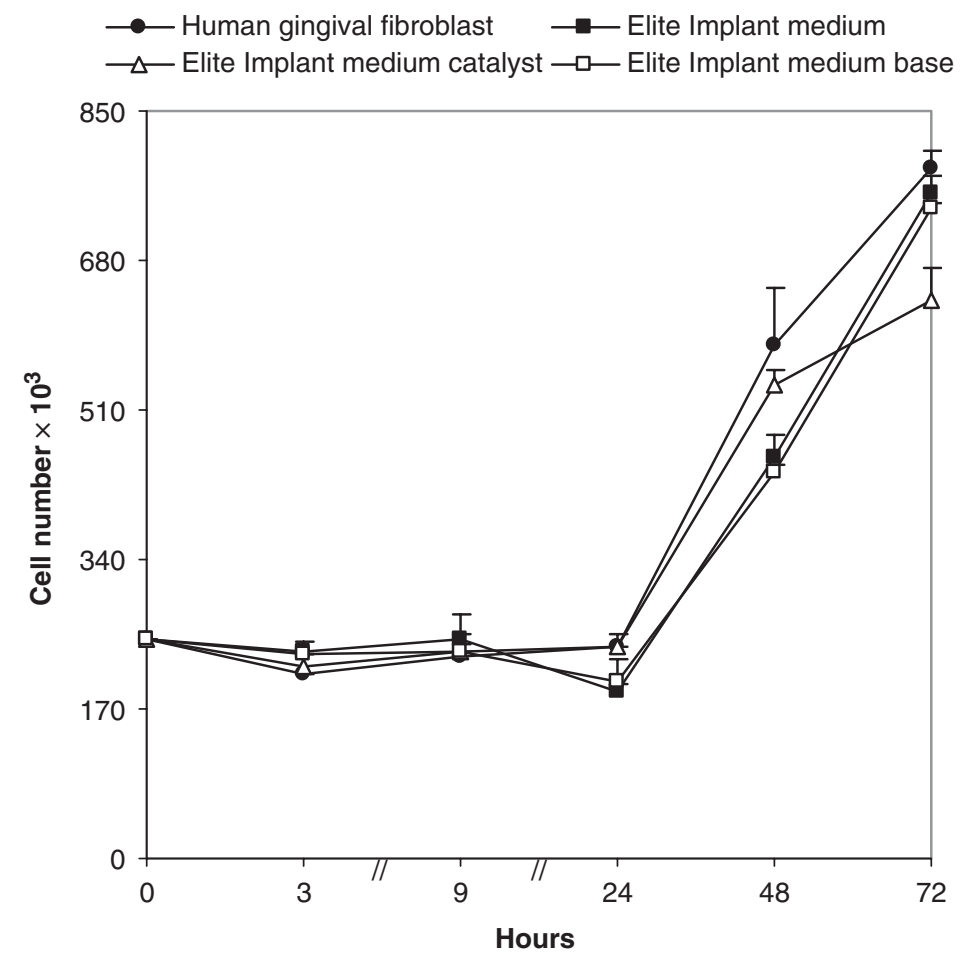

Figure 2. Direct effect of Elite Implant medium viscosity polymerized and its components, base and catalyst pastes, on in vitro proliferation of human gingival fibroblasts. Each point represents the mean of four measurements \pm SD.

did not inhibit cell proliferation at $48 \mathrm{~h}$. At $72 \mathrm{~h}$, Elite Implant heavy viscosity induced a negligible inhibitory effect, $8 \pm 1 \%$ lower than that found in control specimens (Figure 1). Elite Implant medium viscosity also produced a negligible inhibitory effect, $13 \pm 4 \%$ lower than that found in the control cells at $48 \mathrm{~h}$, and at $72 \mathrm{~h}$, the Elite Implant medium catalyst produced a clear inhibitory effect, $\approx 19 \pm 5 \%$ (Figure 2 ). Similar effects on cell proliferation were obtained by Elite Implant light viscosity and its components (Figure 3).

\section{Indirect Effect of Elite Implant on the Viability of Human Gingival Fibroblasts Cultured in vitro}

The diluted (50\%) and undiluted (100\%) extracts obtained after incubation for $24 \mathrm{~h}$ of the heavy, medium, and light Elite Implant materials did not induce any alteration in cellular viability (Figure 4). 


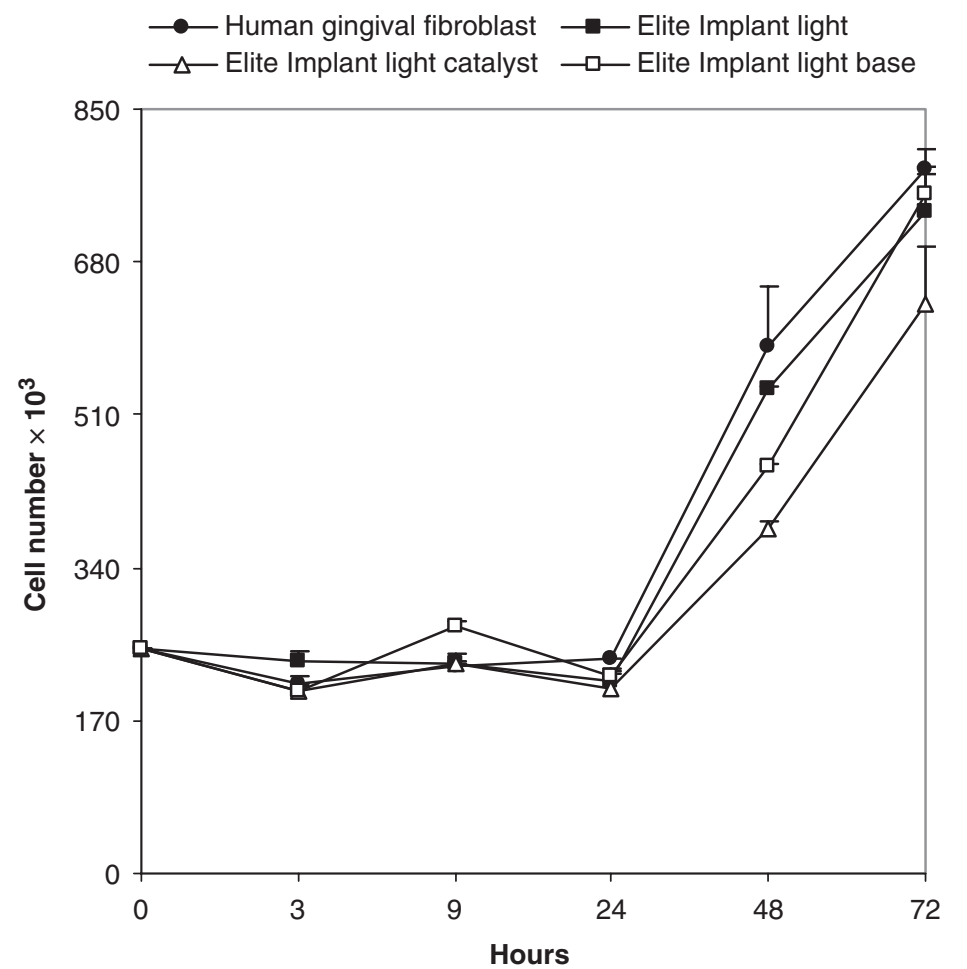

Figure 3. Direct effect of Elite Implant light viscosity polymerized and its components, base and catalyst pastes, on in vitro proliferation of human gingival fibroblasts. Each point represents the mean of four measurements \pm SD.

\section{Morphologic Analysis of Human Gingival Fibroblasts} Cultured in the Presence of Elite Implant Heavy Viscosity Polymerized and its Components - Base and Catalyst Pastes

At $48 \mathrm{~h}$, human gingival fibroblasts, grown without impression material, were uniformly distributed and elongated in the petri dishes, showing typical fibroblast morphology (Figure 5A). In the presence of polymerized Elite Implant heavy viscosity (Figure 5B) and its components, base and catalyst pastes (Figure 5C and D), the culture of fibroblasts, did not show any morphological alteration. The growth and morphology of cells were similar to that of the control culture with some mitosis observed. At $72 \mathrm{~h}$, the gingival fibroblasts were homogeneously distributed on the substrate and produced a complete monolayer. The cells increased in number and appeared with a narrow 


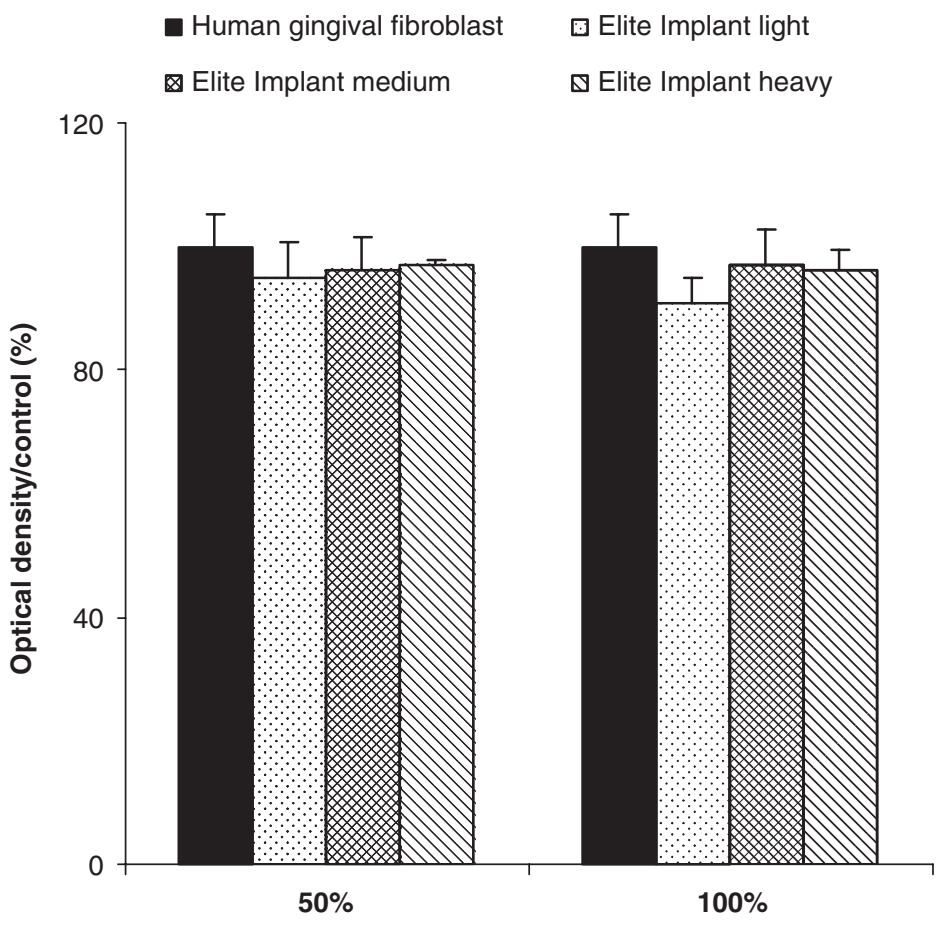

Figure 4. Indirect effect of diluted (50\%) and undiluted (100\%) extracts of Elite Implant heavy, medium, and light viscosity obtained after $24 \mathrm{~h}$ of incubation on cell viability of human gingival fibroblasts. Data are expressed as a percentage of optical density $( \pm \mathrm{SD})$ compared with control cells (\% of control).

and elongated morphology (Figure 6A). The morphology of gingival fibroblasts grown in the presence of Elite Implant Heavy viscosity polymerized and its components is similar to that of the control cells (Figure 6B-D).

\section{DISCUSSION}

The aim of the present study was to evaluate the cytotoxicity of Elite Implant (Zhermack), a new elastomeric, sterile, and radiopaque impression material.

In vitro cytotoxicity tests were developed to simulate and predict biological reactions to the materials placed into or on human tissues. Considering this aim, particular care should be taken to select cell types and experimental conditions. Continuous cell lines are easy to 

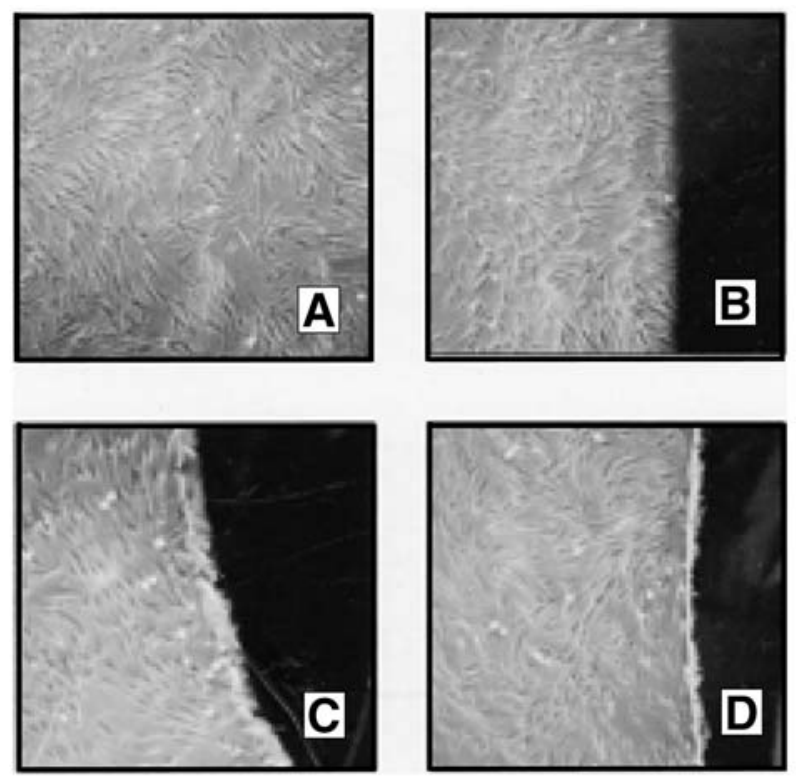

Figure 5. Morphological analysis of human gingival fibroblasts cultured for $48 \mathrm{~h}$ in the absence of impression material (A); in the presence of polymerized Elite Implant heavy viscosity (B); in the presence of base paste (C); and in the presence of catalyst paste (D). Cell cultures were observed by inverted microscopy in phase contrast mode at $\times 50$ magnification.

maintain; they grow quickly and show good reproducibility. They are simple replicating systems without the specific metabolic potential that the target cells have in vivo. Moreover, continuous lines are sensitive and useful to test and classify the toxic effect of different materials [32]. In the present study, the cytotoxicity of this new dental material was assessed using human gingival fibroblasts cultured in vitro. These cells are characterized by a high degree of differentiation even if they are less homogeneous and sensitive than permanent cell lines; they are more comparable in their reaction pattern to oral mucosa. Human gingival fibroblasts retain specialized features and can represent a good simulation of the in vivo condition particularly in the case of impression material retention [31]. Elite Implant was found not to affect cellular proliferation and viability. This result confirms other reports $[9,10,12]$ and also indicates that the manufacturing process and the components, added to the material in order to make it sterile and radiopaque, do not make it cytotoxic to 

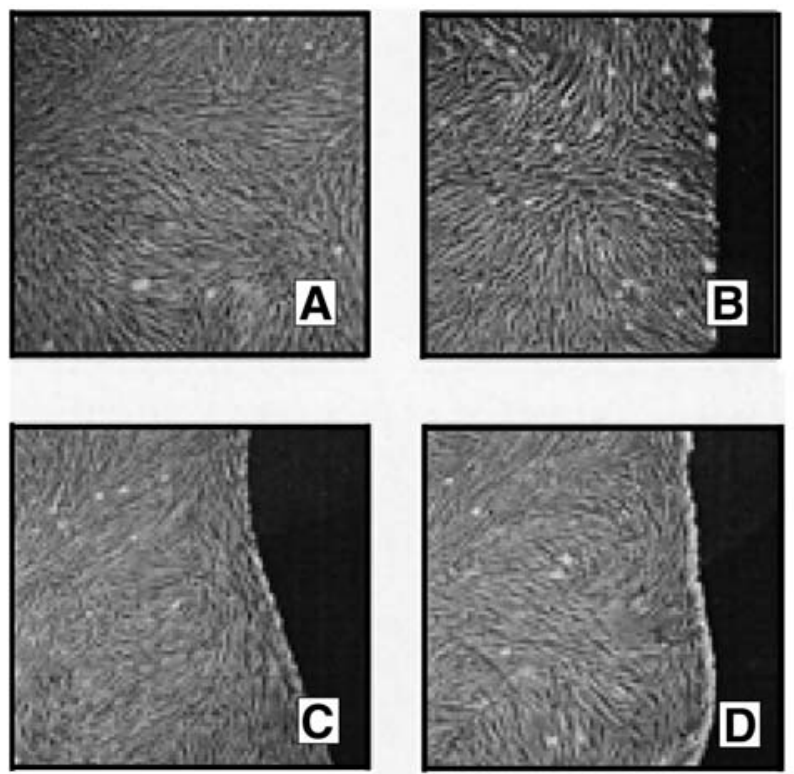

Figure 6. Morphological analysis of human gingival fibroblasts cultured for $72 \mathrm{~h}$ in the absence of impression material (A); in the presence of polymerized Elite Implant heavy viscosity (B); in the presence of base paste (C); and in the presence of catalyst paste (D). Cell cultures were observed by inverted microscopy in phase contrast mode at $\times 50$ magnification.

human gingival fibroblasts. The cytotoxicity of Elite Implant was studied directly on gingival fibroblasts proliferation for $72 \mathrm{~h}$. Generally, impression materials remain in contact with the oral tissues for a short time, typically a few minutes. Only in the situation of material retention in the oral tissues is the time of contact longer. In this case, a moderate or severe swelling of oral tissues may occur. If the impression material is radiopaque, the diagnosis of the swelling can be conducted with simple radiography [20-23].

According to the directive 93/42 CEE for medical devices [35], all noninvasive devices that come into contact with injured skin are classified into different classes. Class I includes the medical devices used as a mechanical barrier, for absorption of exudates. Class IIa includes medical devices intended to manage the micro-environment of a wound. Class IIb includes medical devices used principally in wounds which have breached the dermis and only heal by secondary intent. Elite Implant is the only elastomeric impression material classified in Class 
IIa. Because of its sterility, it has an elective use in operating theaters, specific indications include regenerative bone surgery, intraoperative impressions, immediately loaded implant-supported prostheses, and when making impressions of sub-gingival implant platforms. Finally, the bright color (blue or yellow) of Elite Implant may help the dentist to visualize fragments left intraorally.

\section{ACKNOWLEDGMENT}

This study has been conducted with the help of grants from Italian MURST-MUIR and Zhermack, Badia Polesine, Rovigo, Italy.

\section{REFERENCES}

1. Craig, R.G. and Powers, J.M. (2002). Restorative Dental Materials, 11th edn, St. Louis: Mosby, pp. 348-370.

2. ISO document, 10993 (1994). Biological Compatibility of Medical Devices Part 1. Introduction to the Standards.

3. Brunton, P.A., Christensen, G.J., Cheung, S.W., Burke, F.J. and Wilson, N.H. (2005). Contemporary Dental Practice in the UK: Indirect Restorations and Fixed Prosthodontics, Br. Dent. J., 198: 99-103.

4. Nally, F.F. and Storrs, J. (1973). Hypersensitivity to a Dental Material: A Case Report, Br. Dent. J., 134: 244-246.

5. Craig, R.G. (1982). Characteristics and Clinical and Tissue Reactions of Impression Materials, In: Smith, D.C. and Williams, D.F. (eds), Biocompatibility of Dental Materials, CRC Press, Boca Raton, pp. 277-289.

6. Hensten-Pettersen, A., Nilner, K. and Moller, B. (1990). Guinea Pig Maximization Test with a Polyether Impression Material, Scand. J. Dent. Res., 98: 356.

7. Samaranayake, L.P., Hunjan, M. and Jennings, K.J. (1991). Carriage of Oral Flora on Irreversible Hydrocolloid and Elastomeric Impression Materials, J. Prosthet. Dent., 65: 244-249.

8. Sydiskis, R.J. and Gerhardt, D.E. (1993). Cytotoxicity of Impression Materials, J. Prosthet. Dent., 69: 431-435.

9. Tiozzo, R., Magagna, F., Boraldi, F., Croce, M.A., Bortolini, S. and Consolo, U. (2003). Study of the Potential Cytotoxicity of Dental Impression Materials, Toxicol. in Vitro, 17: 657-662.

10. Chen, S.Y., Chen, C.C. and Kuo, H.W. (2002). Cytotoxicity of Dental Impression Materials, Bull Environ. Contam. Toxicol., 69: 350-355.

11. Ciapetti, G., Granchi, D., Stea, S., Savarino, L., Verri, E., Gori, A., Savioli, F. and Montanaro, L. (1998). Cytotoxicity Testing of Materials with Limited in vivo Exposure is Affected by the Duration of Cell-material Contact, $J$. Biomed. Mater. Res., 42: 485-490. 
12. Marshak, B.L., Cardash, H.S. and Ben-Ur, Z. (1987). Incidence of Impression Material Found in the Gingival Sulcus after Impression Procedure for Fixed Partial Dentures, J. Prosthet. Dent., 57: 306-308.

13. Shen, C. (2003). Impression Materials, In: Anusavice, K.J. (ed.), Phillips' Science of Dental Materials, 11th edn, Philadelphia: CV Saunders, pp. 205-254.

14. Schow, C.E. (1971). Trismus from Unusual Foreign Body in Pterygomandibular Space: Report of a Case, J. Oral Surg., 29: 497.

15. Prince, C. and Whitehead, I.H. (1972). Impression Materials as Foreign Bodies, Br. Dent. J., 133: 9-14.

16. O’Leary, T.J., Standish, S.M. and Bloomer, R.S. (1973). Severe Periodontal Destruction Following Impression Procedures, J. Periodontol., 44: $43-48$.

17. Garey, R.C. and Narang, R. (1976). An Unusual Foreign Body in the Buccal Vestibule: Report of a Case, Oral Med. Oral Surg. Oral Pathol., 42: 314-315.

18. Gullet, C.E. and Caulder, S.L. (1978). Residual Fragment of Rubber Base Material, Operative Dent., 3: 250-252.

19. Shiloah, J., Schuman, N.J., Covington, J.S. and Turner, J.E. (1988). Periodontal Hazards of Retained Impression Materials, Quintessence Int., 19: $143-147$.

20. Ree, M.H. (2001). An Unusual Swelling Following Endodontic and Prosthodontic Treatment of a Mandibular Molar due to a Foreign Body Reaction, Int. Endod. J., 34: 562-567.

21. Olson, R.E. (1968). Foreign Body Removal: Report of a Case, J. Am. Dent. Assoc., 76: 1041-1042.

22. Gettleman, L. and Agranat, B.J. (1976). Polysulfide Rubber Foreign Body: Report of a Case, Quintessence Int., 7: 21.

23. Eliasson, S.T. and Haasken, B. (1979). Radiopacity of Impression Materials, Oral Surg. Oral Med. and Oral Pathol., 47: 485-491.

24. Kent, W.A., Shillingburg, H.T. and Tow, H.D. (1988). Impression Material Foreign Body: Report of a Case, Quintessence Int., 19: 339-345.

25. Eliasson, S.T. and Holte, N.O. (1979). Rubber-base Impression Material as Foreign Body: Report of a Case, Oral Surg. Oral Med. Oral Pathol., 48: 379-380.

26. Glenwright, H.D. (1975). Bone Regeneration Following Damage by Polysulphide Impression Material, J. Periodontol., 2: 250-252.

27. Karanek, B. (1965). Foreign Body in the Antrum, Br. Dent. J., 118: 24.

28. Winstock, D. and Warnakulasuriya, S. (1986). Impression Material Presenting in the Maxillary Antrum as a Foreign Body, Br. Dent. J., 160: 54-55.

29. Smith, H.W. and Guttenberg, I. (1968). Dental Impression Paste in the Maxillary Sinus, Arch. Otolaryngol., 87: 174-180.

30. Lownie, J.F., Lemmer, J. and Sykes, L (1989). Chronic Maxillary Sinusitis Resulting from Displacement of Impression Material into the Maxillary Antrum: A Case Report, J. Dent. Assoc. S. Afr., 44: 341-342. 
31. Kasten, F.H., Felder, S.M., Gettleman, L. and Alchediak, T. (1982). A Model Culture System with Human Gingival Fibroblasts for Evaluating the Cytotoxicity of Dental Materials, In Vitro, 18: 650-660.

32. Lang, H. and Mertens, T.H. (1990). The Use of Cultures of Human Osteoblast like Cells as an In Vitro Test System for Dental Materials, J. Oral Maxillofac. Surg., 48: 606-611.

33. Mosmann, T. (1983). Rapid Colorimatric Assay for Cellular Growth and Survival: Application to Proliferation and Cytotoxicity Assays, J. Immunol. Methods, 65: 55-63.

34. Twentyman, P.R. and Luscombe, M. (1987). A Study of Some Variables in a Tetrazolium Dye (MTT) Based Assay for Cell Growth and Chemiosensitivity, Br. J. Cancer, 56: 279-285.

35. Directive 93/42/CEE du Conseil, du 14 juin 1993, relative aux dispositifs medicaux, Journal official n ${ }^{\circ}$ L 169 du 12/07/1993: 1-43. Edition speciale finnoise, 13,24 p. 85 